\title{
Bio-electrical Impedance Analysis of Oral Cavity Mucosae in Patients With Lichen Planus and Healthy Controls
}

\author{
Alessia Cerrato \\ University of Padua \\ Matteo Cocco \\ University of Padua \\ Gastone Zanette \\ University of Padua \\ Anna Chiara Frigo \\ University of Padua \\ Christian Bacci ( $\nabla$ christian.bacci@unipd.it) \\ University of Padua
}

\section{Research Article}

Keywords: Cancer, Diagnostic procedure, Oral Lichen Planus, Oral Cancer, Oral Lesions, Oral medicine, Pathology, Stomatognathic Diseases

Posted Date: March 3rd, 2021

DOI: https://doi.org/10.21203/rs.3.rs-254678/v1

License: (c) (1) This work is licensed under a Creative Commons Attribution 4.0 International License. Read Full License 


\section{Abstract}

\section{OBJECTIVE}

Oral lichen planus (OLP) is a chronic inflammatory. Bio-electrical impedance analysis (BIA) is a method for assessing tissue composition. Based on a combination of reactance and resistance data, a phase angle (PA) is calculated. The PA may range in value from $90^{\circ}$ to $0^{\circ}$, correlates with body cell mass. There is evidence suggesting that the PA of neoplastic tissue is lower than that of normal tissue. The aim of the present study was to compare the findings of BIA on the oral mucosae of patients with OLP and healthy controls.

\section{MATERIALS AND METHODS}

BIA measurements were obtained with a specific device and PA values were calculated, in a sample of 57 consecutive cases OLP and 60 healthy controls. Impedance measurements were taken for the buccal mucosae, tongue, hard palate and upper anterior gums.

\section{RESULTS}

The resistance, reactance and PA of the hard plate and gums were generally higher in the OLP group than in the control group, and the differences were statistically significant. The median PA of healthy and reticular lesions was higher than that of erosive lesions.

\section{CONCLUSIONS}

These results support the usefulness of BIA for the characterization of healthy oral mucosa and OLP lesions.

\section{Introduction}

Oral lichen planus (OLP) is an inflammatory disease that is generally considered of autoimmune origin (Gorouhi et al., 2014). The most common sites of OLP are the cheeks, tongue, and adherent gingiva. The palate, oral floor and labial mucosa are less frequently involved. OLP lesions are generally bilateral, while single sites of OLP are uncommon (Eisen, 2002). The clinical manifestations of OLP vary, and were classified by Andreasen as comprising six different types: reticular, papular, plaque, atrophic, erosive, and bullous (Andreasen, 1968). A simplified classification proposed by Eisen distinguishes only between reticular, erythematous and erosive OLP lesions (Eisen, 2003). The incidence of carcinoma associated with OLP in the literature is reportedly less than $0.5 \%$, although some studies indicated percentages of neoplastic transformation ranging from $0 \%$ to $5.3 \%$ (Murti et al., 1986; Holmstrup et al., 1988; Salem, 1989; Van der Meij et al., 2003; Voute et al. 1992; Barnard et al., 1993; Brown et al., 1993; Gorsky et al. 1996; Vescovi, 1996; Silverman, 1997; Lo Muzio et al., 1998; Rajentheran et al., 1999; Cowan et al., 2001; Rode, 2002; Yaacob et al., 2002; Gandolfo et al., 2004; Rodstrom et al., 2004). 
Bioelectrical impedance analysis (BIA) of body composition is a technique used to assess the lean mass, fat mass, and fluids in a biological conductor. BIA involves applying a harmless low-intensity (400-800 $\mu \mathrm{A}$ ) alternating electrical current to an organic tissue, and measuring the intensity of the output current. The characteristics of a body's electrical conductivity can cause modifications in the output current being measured.

The first step in a BIA is to record the electrical resistance and reactance of a whole body or a body segment. This data acquisition is done by attaching four electrodes, two of which (the "injection" electrodes) are used to deliver an electrical current of known, constant intensity and high frequency through the body, while the other two ("sensor" electrodes) identify the difference in electrical potential induced by the current's passage through the tissues.

From the physical standpoint, the bioelectrical impedance is the sum of two components - resistance and reactance - according to the formula (Kasap, 1997);

$\mathrm{Z} 2=\mathrm{R} 2+\mathrm{Xc} 2$

Where: $\mathrm{Z}$ is the impedance; $\mathrm{R}$ is the resistance; and $\mathrm{Xc}$ is the reactance.

BIA 101 ANNIVERSARY is an impedance vector analyzer for evaluate the hydration and nutritional status of a body. In technical terms, the electrical properties of the tissues (Resistance, Reactance, Phase Angle) are detected in real time and an estimate of the body components is made. The classic bioimpedance analysis with BIA 101 ANNIVERSARY is obtained with the tetra polar technique, with sinusoidal current at $50 \mathrm{kHz}$ frequency. The current value is kept constant at $330 \mathrm{uA}$ RMS on loads from 1 to $5000 \Omega$. To saturate the whole organism with the current, the injectors are positioned distally on the metacarpal and metatarsal line through surface electrodes, while to detect the segmental data of resistance, reactance and phase angle inside the oral cavity, special four-pointed electrodes, which simultaneously act as the point of entry and exit of the electric current, so as to close the circuit.

The aim of the present experimental study was to examine whether the BIA device enables the identification of lesions or modifications of the oral mucosae by revealing differences in impedance measured in the tissues of OLP patients as compared with healthy controls

\section{Resistance, Reactance and Phase Angle}

All substances oppose a degree of resistance to the passage of an electrical current. The electrical resistance of the human body is inversely proportional to the total amount of water it contains. This means that a well-hydrated individual will have a lower electrical resistance than one who is dehydrated (Kasap, 1997; Kyle et al., 2004; De Lorenzo et al., 1997). Tissues containing little fat are good electrical conductors, i.e. they offer a low resistance, because they contain larger amounts of water and electrolytes. Conversely, adipose tissues and bone are poor conductors because they are low in fluid content, and they offer a high resistance to the passage of an electrical current. The electrical resistance 
of a tissue thus depends not only on the water content of the body as a whole, but also on its proportional distribution in the various types of tissue (Kyle et al., 2004).

Reactance is a force that opposes the passage of an electrical current to a degree that depends on the capacitance of a system involved or, in other words, its capacity to store and electrical charge. In the human body, the cellular membrane forms a thin (insulating) lipid layer separating two environments rich in fluids and proteins (conductors), and it is an excellent example of a capacitor. That is why the cell has a reactance that opposes the passage of the electrical current (Kasap, 1997). In practical terms, this phenomenon is common to all types of cell - except for adipocytes, which are full of fatty material and therefore have good insulating qualities, but lack capacitance. A body's reactance is consequently proportional to the cellular mass of the lean tissues. It is also important to mention that, to develop a reactance, cells must be in good physiological condition. Cellular suffering is generally associated with a gradual drop in the electrical potential of the membrane because the cellular pumps become less able to maintain an adequate gradient between the ions inside and outside the cell (Kasap, 1997; De Lorenzo et al., 1997).

The phase angle is a linear value correlating the resistance with the reactance of an electrical circuit. The phase angle can vary between $0^{\circ}$ and $90^{\circ}$. Lower phase angles are associated with a low resistance or a low reactance, which may mean an expansion of the extracellular spaces due to water retention, or a loss of cellular membrane function due to necrosis, for example. Higher phase angles are associated with a high resistance or high reactance, and may indicate states of dehydration, or considerable quantities of intact cellular membranes, for example. The phase angle can be therefore taken as a prognostic indicator of the state of cellular membrane integrity. The use of BIA has enabled rapid progress to be made in numerous fields, including dietology, nephrology (Norman et al., 2012), surgery, cardiology, hemodynamics, and sports medicine (Khalil et al., 2014).

The present experimental study involved the use of a specific medical device for measuring the bioelectrical impedance of soft tissues in the oral cavity. A substantial difference in electrical impedance has been demonstrated between healthy and tumorous tissues in the oral cavity, and between clinically healthy areas of the oral cavity and other areas showing signs of erosive OLP. Tumor tissues and areas of erosive OLP both coincide with a much lower phase angle than that of healthy tissue (Tatullo et al., 2015).

\section{Materials And Methods}

\section{STUDY POPULATION}

Consecutive patients with a clinically- and histologically-confirmed diagnosis of OLP were recruited to join our group of "cases". The patients enrolled in the study were being followed up at the Oral Medicine and Pathology outpatient service at the University of Padua (Italy), where BIA was implemented as part of routine clinical practice. Exclusion criteria for this group of patients involved the use of nonremovable electronic devices, pacemakers, internal defibrillators, or cochlear implants. A control group, matched for 
age and sex, of subjects with clinically healthy oral cavity mucosae, and no medical history of diseases that might affect the oral cavity, who also met the above exclusion criteria regarding nonremovable electronic devices. All candidates for the control group submitted to a clinical examination to establish the absence of any oral cavity lesions or signs of disease.

In the graphs and tables, any lesions are identified by means of numerical values: 0 (no lesions), 1 (striations), 2 (erythema or erosion) (Eisen, 2003). The areas of oral cavity taken into consideration were: the right and left cheeks, the tongue, the hard palate, and the adherent gingiva. Lesions mapped during the study as erythematous/erosive with striations were included in the group of purely erythematous/erosive lesions because such lesions are still classed as erythematous/erosive in the literature, even in the presence of striations (Olson et al., 2016).

The impedance measurements obtained were compared between cases and controls, and also between all clinically-healthy areas of the oral cavities in the two groups. A comparison was also drawn between the various lesions identified in the group of OLP cases. Although the temperature of the area of oral cavity analyzed was recorded by the device, it was not considered for the purposes of our study because it is strongly influenced by the room temperature as well as that of the tested individual's body (as explained in the device manufacturer's instructions).

The study was approved (702/2020 protocol) by Ethical Committee of Padova Teaching Hospital and was conducted according to the declaration of Helsinki, informed consent was always obtained.

\section{ANALYTICAL METHOD}

BIA was conducted with a device (Akern, BIA 101 Anniversary) complete with a special sensor and four electrodes for placing on the area of oral mucosa to record the bio-electrical impedance of the tissue involved.

All measurements were taken by a single operator (M.C.) who had been trained to use the device. The complete measurement procedure took a mean 5 minutes. None of the patients or controls reported any discomfort caused by the procedure, which proved to be technically straightforward, quick to complete, and well tolerated. The measurement procedure involves resting the sensor on an area of oral cavity of interest and waiting until the values it records become stable. These values are then written on a chart designed for said purpose by an assistant, who also records any signs of the lesions characteristic of OLP. Measurements were taken systematically in five areas of the oral cavity: both cheeks, the hard palate, the tongue, and the adherent gingiva.

\section{STATISTICAL ANALYSIS}

The data collected were input in an EXCEL spreadsheet and analyzed using SAS 9.4 (SAS Institute Inc., Cary, NC, USA) for Windows. 
Qualitative data were represented as counts and percentages in each category, and quantitative data as means and standard deviations, medians, and minimum and maximum values. Comparisons between groups (OLP cases versus controls, OLP cases without clinically-identifiable lesions versus controls, and by severity of lesions for OLP cases) were run using the chi-squared test in the case of qualitative variables, and Wilcoxon's rank sum test or the Kruskal Wallis test for quantitative variables (given their non-normal distribution). The Kruskal Wallis test was followed up with the Dwass, Steel, Critchlow-Fligner method for multiple comparisons in the case of statistical significance. The level of significance was set at $5 \%$, and the numerosity of the sample required was established a priori.

\section{Results}

There were 127 subjects recruited for the purposes of this study, 64 cases and 63 controls. Seven subjects ( 4 cases and 3 controls) were excluded from the analysis because it proved impossible to obtain measurements of one or more areas of their oral cavities. It generally proved most difficult to measure the hard palate and adherent gingiva. Three subjects in the control group refused to take part in the study, citing various reasons (lack of time, little interest in the study proposal, and a history of hypersensitivity to numerous materials), and therefore only completed the part of the procedure necessary for the purposes of their own treatment. The two groups included in the statistical analysis thus included 60 clinicallyhealthy controls and 57 patients with clinically- and histologically-confirmed OLP. The group of OLP patients was a mean 60.3 years old (minimum 23, maximum 86 years), and the control group was a mean 63.1 years old (minimum 23, maximum 89). The OLP group consisted of 15 males $(26.32 \%)$ and 42 females (73.68\%). The control group included 29 males (48.3\%) and 31 females (51.67\%).

In the study sample as a whole (cases and controls), 613 areas of the oral cavity were measured, and 2772 numerical values were recorded on the charts, and input in two Excel spreadsheets, arranged so as to obtain one patient for each line, and the various measurements distributed in subsequent columns.

\section{LESIONS IDENTIFIED IN OLP PATIENTS}

Measurements of the hard palate revealed no lesions in 53 patients $(92.98 \%), 2$ patients $(3.52 \%)$ had striations, and 2 had erythematous lesions (3.52\%).

Measurements of the adherent gingiva showed no lesions in 39 patients $(68.42 \%)$, while $5(8.77 \%)$ had striations, $11(19.30 \%)$ had erythematous lesions, 1 (1.75\%) had plaque lichen, and $1(1.75 \%)$ had erythematous lesions with striations.

In the left cheek, no lesions were identified in 21 patients (36.84\%), while 25 (43.86\%) showed striations, 4 $(7.02 \%)$ had pure erythematous/erosive lesions, $6(10.53 \%)$ had erosive lesions associated with striations, and $1(1.75 \%)$ had plaque lichen.

In the right cheek, no lesions were identified in 19 patients (33.33\%), while 28 (49.1\%) showed striations, 9 (15.78\%) had pure erythematous/erosive lesions and 1 (1.75\%) had plaque lichen. 
As for the tongue, 43 patients $(75.44 \%)$ revealed no lesions, and $12(21.05 \%)$ had striations (these lesions have a very particular, characteristic appearance on the tongue, often showing atrophy of the papillae, striated areas, and white lesions), and 2 patients (3.51\%) had erythematous lesions.

\section{COMPARISON BETWEEN OLP PATIENTS AND CONTROLS}

Table 1 summarizes the results deriving from the analysis of the two groups as a whole. There was a statistically significant difference between the resistance and the reactance of the hard palate and adherent gingiva. Note how the two values increase in the group of patients.

\section{COMPARISON BETWEEN MEASUREMENTS OBTAINED IN THE CONTROL GROUP AND IN THE CLINICALLY-HEALTHY AREAS OF ORAL MUCOSA IN THE GROUP OF PATIENTS WITH OLP}

The 57 OLP patients showed no lesions involving the hard palate in 53 cases (92.98\%), and none involving the adherent gingiva in $39(68.42 \%)$, so these two areas were less often affected. Lesions were more commonly found in the cheeks, as only the right cheeks of 19 patients (33.33\%), and the left cheeks of 21 patients $(36.84 \%)$ were without any clinically identifiable lesions. As for the tongue, no lesions were identified in $43(75.43 \%)$ of cases.

On statistical analysis, there were statistically significant differences in the resistance and reactance recorded for the adherent gingiva and hard palate, which were always higher in the group of OLP cases. There was also an increase in the phase angle in the case of the adherent gingiva. No statistically significant differences emerged for the other areas of the oral cavity (Tables 2-3-4-5-6).

\section{COMPARISON BETWEEN THE TYPES OF LESION FOUND IN PATIENTS WITH OLP}

Given the variability in the types of lesion involved in OLP, an effort was also made to compare the BIA findings for the various lesions identified in the group of patients. It was impossible to conduct any statistical analysis for lesions involving the hard palate, however, because of the negligible number of patients with manifest disease involving this area of the oral cavity.

A statistically significant difference in phase angle emerged between the lesions identified in the right cheek. Further analysis of this sub-sample revealed statistically significant difference between the bioelectrical impedance values for the erythematous and erosive lesions on the one hand, and the areas showing no sign of any lesions or only the presence of striations on the other. The difference between the healthy areas and those with striated lesions was not statistically significant (Tables 7-8-9-10).

\section{Discussion}

The heterogeneous nature of their OLP presentation, and the male-to-female ratio (2:3), and mean age of our sample are consistent with the epidemiological data in the literature. 
Clinical examination showed that patients with OLP did not always have related lesions in all areas of their oral cavity. Hence our interest in trying to identify any bioelectrical changes that might reveal subclinical differences.

We found evidence of a higher resistance and reactance of the tissues of the hard palate and adherent gingiva, even without any clinical evidence of disease. This could mean that, even in the absence of apparent lesions, the mucosa of patients with OLP undergoes some bioelectrical changes. Since OLP is a disease that attacks the keratinocytes, in the case considered here we surmise that the most keratinized areas of the oral cavity respond more readily to the inflammatory insult. This situation would be identified by the bio-electrical impedance measurements obtained. An increase in resistance and reactance could mean either an effective increase in cellular mass, or else a thickening of the tissue and consequent reduction in extracellular fluids, with a preserved or even increased capacitance.

Another statistically significant difference of greater relevance for the purposes of this study concerned the right cheek. There was a statistically significant reduction in the phase angle for the erythematous and erosive areas by comparison with the areas of healthy tissue and those with striations. As we know, the absence of lesions or the presence of Wickham striae are characteristic of stable OLP. Lesions of erythematous and erosive type, on the other hand, are evidence of active disease and, according to some authors, they predispose to neoplastic degeneration.

Our findings are compatible with the premises and our study hypotheses, indicating that BIA can reveal differences and, in some situations, identify tissues that have undergone clinically relevant changes.

\section{Conclusions}

BIA of the oral cavity mucosa is a straightforward procedure that can easily be learned, and is quick to complete. It is an inexpensive and noninvasive examination, and it was well tolerated by our patients, who never complained of any discomfort.

Considering also the adequate numerosity of pathological lesions in our sample of OLP patients, the present study demonstrated that BIA can identify anatomical and physiological changes in the mucosa of the oral cavity. It also has the potential to discriminate between different clinically-appreciable lesions.

Given the lack of studies on the topic and the emerging premises, it is to be hoped that further studies will accompany an evolution of this technology.

\section{References}

1. Andreasen JO. Oral lichen planus. A clinical evaluation of 115 cases. Oral Surg Oral Med Oral Pathol. 1968;25:31-42.

2. Barnard NA, Scully C, Eveson JW, Cunningham S, Porter SR. Oral cancer development in patients with oral lichen planus. J Oral Pathol Med 1993;22:421-4. 
3. Brown RS, Bottomley WK, Puente E, Lavigne GJ. A retrospective evaluation of 193 patients with oral lichen planus. J Oral Pathol Med 1993;22:69-72.

4. Cowan CG, Gregg TA, Napier SS, McKenna SM, Kee F. Potentially malignant oral lesions in northern Ireland: a 20-year population-based perspective of malignant transformation. Oral Dis 2001;7:18-24.

5. De Lorenzo A, Andreoli A, Matthie J. Predicting body cell mass with bioimpedance by using theoretical methods: A technological review. J. Appl. Physiol. 1997, 82, 1542-1558.

6. Eisen D. The clinical manifestations and treatment of oral lichen planus. Dermatol Clin. 2003;21:7989.

7. Eisen D. The clinical features, malignant potential, and systemic associations of oral lichen planus: a study of 723 patients. J Am Acad Dermatol. 2002;46(2):207-214.

8. Ficarra G. Manuale di Patologia e Medicina Orale (III ed). McGraw-Hill Companies Milano 2006:7;147-150

9. Gandolfo S, Richiardi L, Carrozzo M, Broccoletti R, Carbone M, Pagano M, et al. Risk of oral squamous cell carcinoma in 402 patients with oral lichen planus: a follow-up study in an Italian population. Oral Oncol 2004;40:77-83.

10. Gorouhi, Davari P, Fazel N. Cutaneous and mucosal lichen planus: a comprehensive review of clinical subtypes, risk factors, diagnosis, and prognosis. Scientific World Journal 2014.

11. Gorsky M, Raviv M, Moskona D, Laufer M, Bodner L. Clinical characteristics and treatment of patients with oral lichen planus in Israel. Oral Surg Oral Med Oral Pathol Oral Radiol Endod 1996;82:644-9.

12. Holmstrup P, Thorn JJ, Rindum J, Pindborg JJ. Malignant development of lichen planuseaffected oral mucosa. J Oral Pathol 1988;17:219-25.

13. Kasap SO. Principles of Electrical Engineering Materials and Devices; McGraw-Hill: New York City, NY, USA, 1997.

14. Khalil SF, Mohktar MS, Ibrahim F. The Theory and Fundamentals of Bioimpedance Analysis in Clinical Status Monitoring and Diagnosis of Diseases. Sensors 2014: 14, 10895-10928

15. Kyle UG, Bosaeus I, De Lorenzo AD, Deurenberg P. Bioelectrical impedance analysis-Part i: Review of principles and methods. Clin. Nutr. 2004;23:1226-1243.

16. LoMuzio L, Mignogna MD, Favia G, Procaccini M, Testa NF, Bucci E. The possible association between oral lichen planus and oral squamous cell carcinoma: a clinical evaluation on 14 cases and a review of the literature. Oral Oncol 1998;34:239- 46.

17. Murti PR, Daftary DK, Bhonsle RB, Gupta PC, Mehta FS, Pindborg JJ. Malignant potential of oral lichen planus: observations in 722 patients from India. J Oral Pathol 1986;15(2):71 - 7.

18. Norman K, Stobäus N, Pirlich M, Bosy-Westphal A. Bioelectrical phase angle and impedance vector analysis-clinical relevance and applicability of impedance parameters. Clin. Nutr. 2012, 31, 854861.

19. Olson MA, Rogers III RS, Bruce AJ. Oral lichen planus. Clinics in Dermatology 2016;34:495-504. 
20. Rajentheran R, McLean NR, Kelly CG, Reed MF, Nolan A. Malignant transformation of oral lichen planus. Eur J Surg Oncol 1999;25:520-3.

21. Rode $M$, Kogoj-Rode M. Malignant potential of the reticular form of oral lichen planus over a 25-year observation period in 55 patients from Slovenia. J Oral Sci 2002;44:109-11.

22. Rodstrom PO, Jontell M, Mattsson U, Holmberg E. Cancer and oral lichen planus in a Swedish population. Oral Oncol 2004; 40:131-8.

23. Salem G. Oral lichen planus among 4277 patients from Gizan, Saudi Arabia. Community Dent Oral Epidemiol 1989;17:322-4.

24. Silverman S Jr, Bahl S. Oral lichen planus update: clinical characteristics, treatment responses, and malignant transformation. Am J Dent 1997;10:259 - 63.

25. Tatullo M, Amantea M, Paduano F, L Santacroce, S gentile, S sacco. Bioimpedance Detection of Oral Lichen Planus Used as Preneoplastic Model. J Cancer 2015;6(10):976 - 83

26. Van der Meij EH, Schepman KP, van der Waal I. The possible premalignant character of oral lichen planus and oral lichenoid lesions: a prospective study. Oral Surg Oral Med Oral Pathol Oral Radiol Endod 2003;96:164 - 71.

27. Vescovi P, Gennari PU. [Oral lichen planus (OLP). Therapeutic guidelines and clinical experience with 71 patients]. Minerva Stomatol 1996;45:501 - 15.

28. Voute AB, de Jong WF, Schulten EA, Snow GB, van der Waal I. Possible premalignant character of oral lichen planus. The Amsterdam experience. J Oral Pathol Med 1992;21:326-9.

29. Yaacob HB, Tan PL, Ngeow WC. Malignancy in oral lichen planus: a review of a group from the Malaysian population. J Oral Sci 2002;44:65-71.

\section{Tables}

Table 1. Comparison between OLP patients and healthy patients (mean and standard deviation). $1=$ Wilcoxon's rank sum test 


\begin{tabular}{|c|c|c|c|}
\hline Variable & P-Value & $\begin{array}{l}\text { Control Group } \\
(\mathrm{N}=60)\end{array}$ & $\begin{array}{l}\text { OLP Patients } \\
(\mathrm{N}=57)\end{array}$ \\
\hline Hard palate_RESISTANCE (Mean \pm SD $(\mathrm{N}))$ & $0.044^{1}$ & $\begin{array}{l}75.7 \pm 13.8 \\
(N=60)\end{array}$ & $\begin{array}{l}80.6 \pm 16.7 \\
(\mathrm{~N}=57)\end{array}$ \\
\hline Hard palate_RESISTANCE (Median (min-max)) & & $\begin{array}{l}74.2(46.0- \\
108.2)\end{array}$ & $\begin{array}{l}82.4(16.2- \\
110.8)\end{array}$ \\
\hline Hard palate_REACTANCE (Mean \pm SD $(\mathrm{N}))$ & $0.020^{1}$ & $\begin{array}{l}14.5 \pm 5.5 \\
(\mathrm{~N}=60)\end{array}$ & $\begin{array}{l}17.0 \pm 6.3 \\
(\mathrm{~N}=57)\end{array}$ \\
\hline Hard palate_REACTANCE (Median (min-max)) & & $13.9(4.8-36.8)$ & $15.9(6.1-35.2)$ \\
\hline Hard Palate_PHASE ANGLE (Mean \pm SD $(\mathrm{N}))$ & $0.054^{1}$ & $\begin{array}{l}10.7 \pm 3.6 \\
(N=60)\end{array}$ & $\begin{array}{l}12.7 \pm 7.7 \\
(\mathrm{~N}=57)\end{array}$ \\
\hline Hard Palate_PHASE ANGLE (Median (min-max)) & & $9.4(5.3-23.9)$ & $11.2(6.3-62.0)$ \\
\hline Hard Palate_TEMPERATURE (Mean \pm SD $(\mathrm{N})$ ) & $<.00011$ & $\begin{array}{l}25.1 \pm 1.0 \\
(N=60)\end{array}$ & $\begin{array}{l}23.9 \pm 1.4 \\
(N=57)\end{array}$ \\
\hline Hard Palate_TEMPERATURE (Median (min-max)) & & $25.3(22.5-27.7)$ & $23.6(21.2-26.8)$ \\
\hline Adherent Gingiva_RESISTANCE (Mean \pm SD $(\mathrm{N}))$ & $<.00011$ & $\begin{array}{l}59.0 \pm 13.8 \\
(\mathrm{~N}=60)\end{array}$ & $\begin{array}{l}78.6 \pm 30.5 \\
(\mathrm{~N}=57)\end{array}$ \\
\hline $\begin{array}{l}\text { Adherent Gingiva_RESISTANCE (Median (min- } \\
\text { max)) }\end{array}$ & & $\begin{array}{l}57.2(32.2- \\
116.5)\end{array}$ & $\begin{array}{l}72.9(31.4- \\
188.6)\end{array}$ \\
\hline Adherent Gingiva_REACTANCE (Mean \pm SD $(\mathrm{N})$ ) & $<.00011$ & $\begin{array}{l}13.6 \pm 5.7 \\
(\mathrm{~N}=60)\end{array}$ & $\begin{array}{l}19.6 \pm 11.8 \\
(\mathrm{~N}=57)\end{array}$ \\
\hline $\begin{array}{l}\text { Adherent Gingiva_REACTANCE (Median (min- } \\
\text { max)) }\end{array}$ & & $12.3(5.9-38.5)$ & $16.2(5.4-66.6)$ \\
\hline Adherent Gingiva_PHASE ANGLE (Mean \pm SD $(\mathrm{N})$ ) & $0.12^{1}$ & $\begin{array}{l}12.7 \pm 2.9 \\
(N=60)\end{array}$ & $\begin{array}{l}13.5 \pm 3.0 \\
(\mathrm{~N}=57)\end{array}$ \\
\hline $\begin{array}{l}\text { Adherent Gingiva_PHASE ANGLE (Median (min- } \\
\text { max)) }\end{array}$ & & $12.5(5.8-21.6)$ & $13.5(5.8-19.7)$ \\
\hline Adherent Gingiva_TEMPERATURE (Mean \pm SD & $<.0001^{1}$ & $25.1 \pm 1.0$ & $24.0 \pm 1.5$ \\
\hline
\end{tabular}




\begin{tabular}{|c|c|c|c|}
\hline$(\mathrm{N}))$ & & $(\mathrm{N}=60)$ & $(\mathrm{N}=57)$ \\
\hline $\begin{array}{l}\text { Adherent Gingiva_TEMPERATURE (Median (min- } \\
\text { max)) }\end{array}$ & & $25.3(22.6-27.7)$ & $23.7(21.1-26.9)$ \\
\hline Left Cheek_RESISTANCE (Mean \pm SD $(\mathrm{N}))$ & $0.12^{1}$ & $\begin{array}{l}65.9 \pm 10.7 \\
(\mathrm{~N}=60)\end{array}$ & $\begin{array}{l}62.5 \pm 9.4 \\
(\mathrm{~N}=57)\end{array}$ \\
\hline Left Cheek_RESISTANCE (Median (min-max)) & & $64.8(47.1-96.5)$ & $62.5(45.1-89.8)$ \\
\hline Left Cheek_REACTANCE $($ Mean \pm SD $(\mathrm{N}))$ & $0.63^{1}$ & $\begin{array}{l}13.8 \pm 2.2 \\
(N=60)\end{array}$ & $\begin{array}{l}13.8 \pm 2.9 \\
(N=57)\end{array}$ \\
\hline Left Cheek_REACTANCE (Median (min-max)) & & $14.0(8.9-19.3)$ & $13.4(7.2-20.5)$ \\
\hline Left Cheek_PHASE ANGLE (Mean \pm SD $(\mathrm{N}))$ & $0.11^{1}$ & $\begin{array}{l}11.9 \pm 1.3 \\
(\mathrm{~N}=60)\end{array}$ & $\begin{array}{l}12.5 \pm 1.9 \\
(\mathrm{~N}=57)\end{array}$ \\
\hline Left Cheek_PHASE ANGLE (Median (min-max)) & & $12.0(9.1-15.8)$ & $12.2(9.1-16.4)$ \\
\hline Left Cheek_TEMPERATURE (Mean \pm SD $(\mathrm{N})$ ) & $<.0001^{1}$ & $\begin{array}{l}24.9 \pm 0.9 \\
(\mathrm{~N}=60)\end{array}$ & $\begin{array}{l}23.6 \pm 1.6 \\
(\mathrm{~N}=57)\end{array}$ \\
\hline Left Cheek_TEMPERATURE (Median (min-max)) & & $25.0(22.8-27.2)$ & $23.4(20.4-26.8)$ \\
\hline
\end{tabular}




\begin{tabular}{|c|c|c|c|}
\hline Right Cheek_RESISTANCE (Mean \pm SD $(\mathrm{N}))$ & $0.10^{1}$ & $\begin{array}{l}66.6 \pm 8.9 \\
(N=60)\end{array}$ & $64.0 \pm 9.9(\mathrm{~N}=57)$ \\
\hline Right Cheek_RESISTANCE (Median (min-max)) & & $66.7(49.4-85.9)$ & $63.6(45.3-92.6)$ \\
\hline Right Cheek_REACTANCE (Mean \pm SD (N)) & $0.091^{1}$ & $\begin{array}{l}14.6 \pm 2.4 \\
(\mathrm{~N}=60)\end{array}$ & $13.9 \pm 2.5(\mathrm{~N}=57)$ \\
\hline Right Cheek_REACTANCE (Median (min-max)) & & $14.6(9.0-21.0)$ & $13.5(8.5-21.9)$ \\
\hline Right Cheek_PHASE ANGLE (Mean \pm SD $(\mathrm{N})$ ) & $0.93^{1}$ & $\begin{array}{l}12.3 \pm 2.0 \\
(N=60)\end{array}$ & $12.2 \pm 1.5(\mathrm{~N}=57)$ \\
\hline Right Cheek_PHASE ANGLE (Median (min-max)) & & $12.1(8.0-20.9)$ & $12.1(9.9-17.7)$ \\
\hline Right Cheek_TEMPERATURE (Mean \pm SD $(\mathrm{N})$ ) & $<.0001^{1}$ & $\begin{array}{l}24.9 \pm 0.9 \\
(\mathrm{~N}=60)\end{array}$ & $23.5 \pm 1.6(\mathrm{~N}=57)$ \\
\hline $\begin{array}{l}\text { Right Cheek_TEMPERATURE (Median (min- } \\
\text { max)) }\end{array}$ & & $25.0(22.7-27.3)$ & $23.4(20.3-26.7)$ \\
\hline Tongue_RESISTANCE (Mean \pm SD (N)) & $0.72^{1}$ & $\begin{array}{l}57.3 \pm 8.3 \\
(\mathrm{~N}=60)\end{array}$ & $\begin{array}{l}58.3 \pm 11.1 \\
(\mathrm{~N}=57)\end{array}$ \\
\hline Tongue_RESISTANCE (Median (min-max)) & & $56.8(35.9-76.7)$ & $55.4(46.0-110.3)$ \\
\hline Tongue_REACTANCE (Mean \pm SD (N)) & $0.35^{1}$ & $\begin{array}{l}15.0 \pm 2.6 \\
(N=60)\end{array}$ & $14.7 \pm 2.7(\mathrm{~N}=57)$ \\
\hline Tongue_REACTANCE (Median (min-max)) & & $14.6(7.8-20.1)$ & $14.4(9.8-24.9)$ \\
\hline Tongue_PHASE ANGLE (Mean \pm SD $(\mathrm{N}))$ & 0.191 & $\begin{array}{l}14.5 \pm 1.2 \\
(\mathrm{~N}=60)\end{array}$ & $14.3 \pm 1.5(\mathrm{~N}=57)$ \\
\hline Tongue_PHASE ANGLE (Median (min-max)) & & $14.6(11.2-17.4)$ & $14.4(11.3-19.1)$ \\
\hline Tongue_TEMPERATURE (Mean \pm SD $(\mathrm{N}))$ & $<.0001^{1}$ & $\begin{array}{l}25.0 \pm 0.9 \\
(\mathrm{~N}=60)\end{array}$ & $23.8 \pm 1.6(\mathrm{~N}=57)$ \\
\hline Tongue_TEMPERATURE (Median (min-max)) & & $25.2(22.9-27.6)$ & $23.5(20.8-26.8)$ \\
\hline
\end{tabular}

Table 2. Comparison between measurements obtained in the control group and in the clinically-healthy 
areas of hard palate in the group of patients affected by OLP.

$1=$ Wilcoxon's rank sum test

\begin{tabular}{|c|c|c|c|}
\hline Variable & P-Value & $\begin{array}{l}\text { Control Group } \\
(\mathrm{N}=60)\end{array}$ & $\begin{array}{l}\text { OLP Patients } \\
(\mathrm{N}=53)\end{array}$ \\
\hline Hard Palate_RESISTANCE (Mean \pm SD $(\mathrm{N}))$ & $0.041^{1}$ & $\begin{array}{l}75.7 \pm 13.8 \\
(N=60)\end{array}$ & $\begin{array}{l}80.7 \pm 17.0 \\
(\mathrm{~N}=53)\end{array}$ \\
\hline Hard Palate_RESISTANCE (Median (min-max)) & & $74.2(46.0-108.2)$ & $82.4(16.2-110.8)$ \\
\hline Hard Palate_REACTANCE (Mean \pm SD $(\mathrm{N})$ ) & $0.012^{1}$ & $14.5 \pm 5.5(\mathrm{~N}=60)$ & $17.2 \pm 6.3(\mathrm{~N}=53)$ \\
\hline Hard Palate_REACTANCE (Median (min-max)) & & $13.9(4.8-36.8)$ & $16.0(6.1-35.2)$ \\
\hline Hard Palate_PHASE ANGLE (Mean \pm SD $(\mathrm{N}))$ & $0.033^{1}$ & $10.7 \pm 3.6(\mathrm{~N}=60)$ & $12.9 \pm 7.9(\mathrm{~N}=53)$ \\
\hline $\begin{array}{l}\text { Hard Palate_PHASE ANGLE (Median (min- } \\
\text { max)) }\end{array}$ & & $9.4(5.3-23.9)$ & $11.4(6.3-62.0)$ \\
\hline Hard Palate_TEMPERATURE (Mean \pm SD $(\mathrm{N})$ ) & $<.0001^{1}$ & $25.1 \pm 1.0(\mathrm{~N}=60)$ & $23.9 \pm 1.5(\mathrm{~N}=53)$ \\
\hline $\begin{array}{l}\text { Hard Palate_TEMPERATURE (Median (min- } \\
\text { max)) }\end{array}$ & & $25.3(22.5-27.7)$ & $23.7(21.2-26.8)$ \\
\hline
\end{tabular}

Table 3. Comparison between measurements obtained in the control group and in the clinically-healthy areas of adherent gingiva in the group of patients affected by OLP.

$1=$ Wilcoxon's rank sum test 


\begin{tabular}{|c|c|c|c|}
\hline Variable & P-Value & $\begin{array}{l}\text { Control Group } \\
(\mathrm{N}=60)\end{array}$ & $\begin{array}{l}\text { OLP Patients } \\
(\mathrm{N}=39)\end{array}$ \\
\hline Adherent Gingiva_RESISTANCE (Mean \pm SD $(\mathrm{N}))$ & $0.0007^{1}$ & $\begin{array}{l}59.0 \pm 13.8 \\
(\mathrm{~N}=60)\end{array}$ & $\begin{array}{l}72.2 \pm 25.4 \\
(\mathrm{~N}=39)\end{array}$ \\
\hline $\begin{array}{l}\text { Adherent Gingiva_RESISTANCE (Median (min- } \\
\text { max)) }\end{array}$ & & $\begin{array}{l}57.2(32.2- \\
116.5)\end{array}$ & $\begin{array}{l}69.6(31.4- \\
188.6)\end{array}$ \\
\hline Adherent Gingiva_REACTANCE (Mean \pm SD $(\mathrm{N}))$ & $0.0004^{1}$ & $\begin{array}{l}13.6 \pm 5.7 \\
(\mathrm{~N}=60)\end{array}$ & $\begin{array}{l}18.2 \pm 9.9 \\
(\mathrm{~N}=39)\end{array}$ \\
\hline $\begin{array}{l}\text { Adherent Gingiva_REACTANCE (Median (min- } \\
\text { max)) }\end{array}$ & & $12.3(5.9-38.5)$ & $15.8(5.4-66.6)$ \\
\hline Adherent Gingiva_PHASE ANGLE (Mean \pm SD $(\mathrm{N})$ ) & $0.061^{1}$ & $\begin{array}{l}12.7 \pm 2.9 \\
(\mathrm{~N}=60)\end{array}$ & $\begin{array}{l}13.7 \pm 2.9 \\
(\mathrm{~N}=39)\end{array}$ \\
\hline $\begin{array}{l}\text { Adherent Gingiva_PHASE ANGLE (Median (min- } \\
\text { max)) }\end{array}$ & & $12.5(5.8-21.6)$ & $13.6(5.8-19.4)$ \\
\hline $\begin{array}{l}\text { Adherent Gingiva_TEMPERATURE (Mean } \pm \text { SD } \\
(\mathrm{N}) \text { ) }\end{array}$ & $<.0001^{1}$ & $\begin{array}{l}25.1 \pm 1.0 \\
(\mathrm{~N}=60)\end{array}$ & $\begin{array}{l}23.8 \pm 1.6 \\
(\mathrm{~N}=39)\end{array}$ \\
\hline $\begin{array}{l}\text { Adherent Gingiva_TEMPERATURE (Median (min- } \\
\text { max)) }\end{array}$ & & $25.3(22.6-27.7)$ & $23.7(21.1-26.9)$ \\
\hline
\end{tabular}

Table 4. Comparison between measurements obtained in the control group and in the clinically-healthy areas of left cheek in the group of patients affected by OLP.

$1=$ Wilcoxon's rank sum test 


\begin{tabular}{|c|c|c|c|}
\hline Variable & P-Value & $\begin{array}{l}\text { Control Group } \\
(\mathrm{N}=60)\end{array}$ & $\begin{array}{l}\text { OLP Patients } \\
(\mathrm{N}=21)\end{array}$ \\
\hline Left Cheek_RESISTANCE (Mean \pm SD $(\mathrm{N}))$ & 0.341 & $\begin{array}{l}65.9 \pm 10.7 \\
(N=60)\end{array}$ & $\begin{array}{l}63.2 \pm 10.4 \\
(\mathrm{~N}=21)\end{array}$ \\
\hline Left Cheek_RESISTANCE (Median (min-max)) & & $64.8(47.1-96.5)$ & $63.0(47.9-89.8)$ \\
\hline Left Cheek_REACTANCE (Mean \pm SD $(\mathrm{N}))$ & $0.62^{1}$ & $13.8 \pm 2.2(\mathrm{~N}=60)$ & $13.8 \pm 2.6(\mathrm{~N}=21)$ \\
\hline Left Cheek_REACTANCE (Median (min-max)) & & $14.0(8.9-19.3)$ & $12.7(10.6-20.5)$ \\
\hline Left Cheek_PHASE ANGLE (Mean \pm SD (N)) & $0.22^{1}$ & $11.9 \pm 1.3(\mathrm{~N}=60)$ & $12.3 \pm 1.6(\mathrm{~N}=21)$ \\
\hline Left Cheek_PHASE ANGLE (Median (min-max)) & & $12.0(9.1-15.8)$ & $12.2(9.3-14.5)$ \\
\hline Left Cheek_TEMPERATURE (Mean \pm SD $(\mathrm{N}))$ & $0.0001^{1}$ & $24.9 \pm 0.9(\mathrm{~N}=60)$ & $23.5 \pm 1.5(\mathrm{~N}=21)$ \\
\hline $\begin{array}{l}\text { Left Cheek_TEMPERATURE (Median (min- } \\
\max \text { )) }\end{array}$ & & $25.0(22.8-27.2)$ & $23.3(21.0-26.8)$ \\
\hline
\end{tabular}

Table 5. Comparison between measurements obtained in the control group and in the clinically-healthy areas of righy cheek in the group of patients affected by OLP.

$1=$ Wilcoxon's rank sum test 


\begin{tabular}{|c|c|c|c|}
\hline Variable & P-Value & $\begin{array}{l}\text { Control Group } \\
(\mathrm{N}=60)\end{array}$ & $\begin{array}{l}\text { OLP Patients } \\
(\mathrm{N}=43)\end{array}$ \\
\hline Right Cheek_RESISTANCE (Mean \pm SD $(\mathrm{N}))$ & 0.19291 & $\begin{array}{l}66.60 \pm 8.94 \\
(N=60)\end{array}$ & $\begin{array}{l}64.2 \pm 9.93 \\
(\mathrm{~N}=19)\end{array}$ \\
\hline $\begin{array}{l}\text { Right Cheek_RESISTANCE (Median (min- } \\
\text { max)) }\end{array}$ & & $66.7(49.4-85.90)$ & $62(52.50-83.10)$ \\
\hline Right Cheek_REACTANCE (Mean \pm SD $(\mathrm{N})$ ) & 0.35871 & $\begin{array}{l}14.57 \pm 2.41 \\
(\mathrm{~N}=60)\end{array}$ & $\begin{array}{l}14.36 \pm 2.55 \\
(\mathrm{~N}=19)\end{array}$ \\
\hline Right Cheek_REACTANCE (Median (min-max)) & & $14.6(9-21)$ & $13.3(11.8-21.9)$ \\
\hline Right Cheek_PHASE ANGLE (Mean \pm SD $(\mathrm{N}))$ & $0.4252^{1}$ & $\begin{array}{l}12.33 \pm 1.96 \\
(\mathrm{~N}=60)\end{array}$ & $\begin{array}{l}12.57 \pm 1.24 \\
(\mathrm{~N}=19)\end{array}$ \\
\hline $\begin{array}{l}\text { Right Cheek_PHASE ANGLE (Median (min- } \\
\text { max)) }\end{array}$ & & $12.1(8-20.9)$ & $12.4(10.9-15.10)$ \\
\hline Right Cheek_TEMPERATURE (Mean \pm SD $(\mathrm{N})$ ) & $0.0006^{1}$ & $\begin{array}{l}24,87 \pm 0.93 \\
(N=60)\end{array}$ & $\begin{array}{l}23.52 \pm 1.6 \\
(\mathrm{~N}=19)\end{array}$ \\
\hline $\begin{array}{l}\text { Right Cheek_TEMPERATURE (Median (min- } \\
\text { max)) }\end{array}$ & & $25(22.7-27.3)$ & 23.10. (20.3-26.7) \\
\hline
\end{tabular}

Table 6. Comparison between measurements obtained in the control group and in the clinically-healthy areas of tongue in the group of patients affected by OLP.

$1=$ Wilcoxon's rank sum test 


\begin{tabular}{|c|c|c|c|}
\hline Variable & P-Value & $\begin{array}{l}\text { Control Group } \\
(\mathrm{N}=60)\end{array}$ & $\begin{array}{l}\text { OLP Patients } \\
(\mathrm{N}=43)\end{array}$ \\
\hline Tongue_RESISTANCE (Mean \pm SD $(\mathrm{N}))$ & $0.91^{1}$ & $57.3 \pm 8.3(\mathrm{~N}=60)$ & $59.0 \pm 12.3(\mathrm{~N}=43)$ \\
\hline Tongue_RESISTANCE (Median (min-max)) & & $56.8(35.9-76.7)$ & $56.7(46.0-110.3)$ \\
\hline Tongue_REACTANCE $($ Mean \pm SD $(\mathrm{N}))$ & $0.29^{1}$ & $15.0 \pm 2.6(\mathrm{~N}=60)$ & $14.7 \pm 2.8(\mathrm{~N}=43)$ \\
\hline Tongue_REACTANCE (Median (min-max)) & & $14.6(7.8-20.1)$ & $14.4(9.8-24.9)$ \\
\hline Tongue_PHASE ANGLE (Mean \pm SD $(\mathrm{N}))$ & $0.090^{1}$ & $14.5 \pm 1.2(\mathrm{~N}=60)$ & $14.1 \pm 1.6(\mathrm{~N}=43)$ \\
\hline Tongue_PHASE ANGLE (Median (min-max)) & & $14.6(11.2-17.4)$ & $14.1(11.3-19.1)$ \\
\hline Tongue_TEMPERATURE (Mean \pm SD $(\mathrm{N}))$ & $<.0001^{1}$ & $25.0 \pm 0.9(\mathrm{~N}=60)$ & $23.9 \pm 1.6(\mathrm{~N}=43)$ \\
\hline Tongue_TEMPERATURE (Median (min-max)) & & $25.2(22.9-27.6)$ & $23.6(21.3-26.8)$ \\
\hline
\end{tabular}

Table 7. Comparison between the types of lesion found in patients affected by OLP (left cheek). The lesions are identified by means of numerical values: 0 (no lesions), 1 (striations), 2 (erythema or erosion).

$1=$ Wilcoxon's rank sum test 


\begin{tabular}{|c|c|c|c|c|}
\hline \multirow[t]{2}{*}{ Variable } & \multirow{2}{*}{$\begin{array}{l}\text { P- } \\
\text { Value }\end{array}$} & 0 & 1 & 2 \\
\hline & & $(\mathrm{N}=21)$ & $(\mathrm{N}=25)$ & $(\mathrm{N}=10)$ \\
\hline $\begin{array}{l}\text { Left Cheek_RESISTANCE (Mean } \pm \text { SD } \\
(\mathrm{N}) \text { ) }\end{array}$ & $0.37^{1}$ & $\begin{array}{l}63.2 \pm 10.4 \\
(\mathrm{~N}=21)\end{array}$ & $\begin{array}{l}63.9 \pm 8.8 \\
(\mathrm{~N}=25)\end{array}$ & $\begin{array}{l}58.3 \pm 8.8 \\
(\mathrm{~N}=10)\end{array}$ \\
\hline $\begin{array}{l}\text { Left Cheek_RESISTANCE (Median (min- } \\
\text { max)) }\end{array}$ & & $\begin{array}{l}63.0(47.9- \\
89.8)\end{array}$ & $\begin{array}{l}62.5(49.1- \\
82.2)\end{array}$ & $\begin{array}{l}61.5(45.1- \\
70.8)\end{array}$ \\
\hline $\begin{array}{l}\text { Left Cheek_REACTANCE (Mean } \pm \text { SD } \\
(\mathrm{N}))\end{array}$ & $0.10^{1}$ & $\begin{array}{l}13.8 \pm 2.6 \\
(\mathrm{~N}=21)\end{array}$ & $\begin{array}{l}14.6 \pm 2.9 \\
(\mathrm{~N}=25)\end{array}$ & $\begin{array}{l}12.2 \pm 3.1 \\
(\mathrm{~N}=10)\end{array}$ \\
\hline $\begin{array}{l}\text { Left Cheek_REACTANCE (Median (min- } \\
\text { max)) }\end{array}$ & & $\begin{array}{l}12.7(10.6- \\
20.5)\end{array}$ & $\begin{array}{l}14.0(10.3- \\
20.5)\end{array}$ & $\begin{array}{l}11.8(7.2- \\
18.5)\end{array}$ \\
\hline $\begin{array}{l}\text { Left Cheek_PHASE ANGLE (Mean } \pm \text { SD } \\
(\mathrm{N}))\end{array}$ & $0.29^{1}$ & $\begin{array}{l}12.3 \pm 1.6 \\
(\mathrm{~N}=21)\end{array}$ & $\begin{array}{l}12.9 \pm 2.0 \\
(\mathrm{~N}=25)\end{array}$ & $\begin{array}{l}11.9 \pm 2.3 \\
(N=10)\end{array}$ \\
\hline $\begin{array}{l}\text { Left Cheek_PHASE ANGLE (Median } \\
(\text { min-max)) }\end{array}$ & & $12.2(9.3-14.5)$ & $\begin{array}{l}12.6(9.2- \\
16.3)\end{array}$ & $\begin{array}{l}11.4(9.1- \\
16.4)\end{array}$ \\
\hline $\begin{array}{l}\text { Left Cheek_TEMPERATURE (Mean } \pm \\
\text { SD (N)) }\end{array}$ & $0.18^{1}$ & $\begin{array}{l}23.5 \pm 1.5 \\
(\mathrm{~N}=21)\end{array}$ & $\begin{array}{l}23.5 \pm 1.6 \\
(\mathrm{~N}=25)\end{array}$ & $\begin{array}{l}24.4 \pm 1.5 \\
(\mathrm{~N}=10)\end{array}$ \\
\hline $\begin{array}{l}\text { Left Cheek TEMPERATURE (Median } \\
\text { (min-max)) }\end{array}$ & & $\begin{array}{l}23.3(21.0- \\
26.8)\end{array}$ & $\begin{array}{l}23.4(20.4- \\
26.4)\end{array}$ & $\begin{array}{l}24.5(21.5- \\
26.8)\end{array}$ \\
\hline
\end{tabular}

Table 8. Comparison between the types of lesion found in patients affected by OLP (right cheek). The lesions are identified by means of numerical values: 0 (no lesions), 1 (striations), 2 (erythema or erosion).

$1=$ Wilcoxon's rank sum test 


\begin{tabular}{|c|c|c|c|c|}
\hline \multirow[t]{2}{*}{ Variable } & \multirow[t]{2}{*}{ P-Value } & 0 & 1 & 2 \\
\hline & & $(\mathrm{N}=19)$ & $(\mathrm{N}=28)$ & $(\mathrm{N}=9)$ \\
\hline $\begin{array}{l}\text { Right Cheek_RESISTANCE (Mean } \pm \text { SD } \\
(\mathrm{N}))\end{array}$ & $0.90^{1}$ & $\begin{array}{l}64.2 \pm 8.9 \\
(\mathrm{~N}=19)\end{array}$ & $\begin{array}{l}63.8 \pm 9.7 \\
(\mathrm{~N}=28)\end{array}$ & $\begin{array}{l}64.2 \pm 13.8 \\
(\mathrm{~N}=9)\end{array}$ \\
\hline $\begin{array}{l}\text { Right Cheek_RESISTANCE (Median } \\
\text { (min-max)) }\end{array}$ & & $\begin{array}{l}62.0(52.5- \\
83.1)\end{array}$ & $\begin{array}{l}62.7(46.6- \\
92.6)\end{array}$ & $\begin{array}{l}68.3(45.3- \\
81.6)\end{array}$ \\
\hline $\begin{array}{l}\text { Right Cheek_REACTANCE (Mean } \pm \text { SD } \\
\text { (N)) }\end{array}$ & $0.58^{1}$ & $\begin{array}{l}14.4 \pm 2.5 \\
(\mathrm{~N}=19)\end{array}$ & $\begin{array}{l}14.0 \pm 2.3 \\
(\mathrm{~N}=28)\end{array}$ & $\begin{array}{l}12.6 \pm 2.8 \\
(\mathrm{~N}=9)\end{array}$ \\
\hline $\begin{array}{l}\text { Right Cheek_REACTANCE (Median (min- } \\
\text { max)) }\end{array}$ & & $\begin{array}{l}13.3(11.8- \\
21.9)\end{array}$ & $\begin{array}{l}13.5(9.8- \\
19.8)\end{array}$ & $\begin{array}{l}13.3(8.5- \\
16.7)\end{array}$ \\
\hline $\begin{array}{l}\text { Right Cheek_PHASE ANGLE (Mean } \pm \text { SD } \\
\text { (N)) }\end{array}$ & $0.0099^{1}$ & $\begin{array}{l}12.6 \pm 1.2 \\
(\mathrm{~N}=19)\end{array}$ & $\begin{array}{l}12.4 \pm 1.7 \\
(\mathrm{~N}=28)\end{array}$ & $\begin{array}{l}11.1 \pm 0.6 \\
(\mathrm{~N}=9)\end{array}$ \\
\hline $\begin{array}{l}\text { Right Cheek_PHASE ANGLE (Median } \\
\text { (min-max)) }\end{array}$ & & $\begin{array}{l}12.4(10.9- \\
15.1)\end{array}$ & $\begin{array}{l}12.3(9.9- \\
17.7)\end{array}$ & $\begin{array}{l}10.9(10.5- \\
12.1)\end{array}$ \\
\hline $\begin{array}{l}\text { Right Cheek_TEMPERATURE (Mean } \pm \\
\text { SD (N)) }\end{array}$ & $0.24^{1}$ & $\begin{array}{l}23.5 \pm 1.7 \\
(\mathrm{~N}=19)\end{array}$ & $\begin{array}{l}23.3 \pm 1.6 \\
(\mathrm{~N}=28)\end{array}$ & $\begin{array}{l}24.3 \pm 1.2 \\
(\mathrm{~N}=9)\end{array}$ \\
\hline $\begin{array}{l}\text { Right Cheek_TEMPERATURE (Median } \\
\text { (min-max)) }\end{array}$ & & $\begin{array}{l}23.1(20.3- \\
26.7)\end{array}$ & $\begin{array}{l}23.4(20.8- \\
26.4)\end{array}$ & $\begin{array}{l}24.0(23.0- \\
26.5)\end{array}$ \\
\hline
\end{tabular}

Table 9. Comparison between lesions of the right cheek areas. Dwass, Steel, Critchlow-Fligner multiple comparison procedure

\begin{tabular}{|llll|}
\hline & Wilcoxon Z & DSCF Value & $\operatorname{Pr}>$ DSCF \\
\hline No lesions vs Striation & 0,6509 & 0,9205 & 0,7918 \\
\hline No lesions vs Erythema or Erosion & 3,1275 & 4,423 & 0,005 \\
\hline Striation vs Erythema or Erosion & 2,4279 & 3,4336 & 0,0403 \\
\hline
\end{tabular}

Table 10. Comparison between the types of lesion found in patients affected by OLP (tongue). The lesions are identified by means of numerical values: 0 (no lesions), 1 (striations), 2 (erythema or erosion).

$1=$ Wilcoxon's rank sum test 


\begin{tabular}{|c|c|c|c|}
\hline \multirow[t]{2}{*}{ Variable } & \multirow[t]{2}{*}{ P-Value } & 0 & 1 \\
\hline & & $(\mathrm{N}=43)$ & $(\mathrm{N}=12)$ \\
\hline Tongue_RESISTANCE $($ Mean \pm SD $(\mathrm{N}))$ & $0.30^{1}$ & $59.0 \pm 12.3(\mathrm{~N}=43)$ & $55.1 \pm 5.3(\mathrm{~N}=12)$ \\
\hline Tongue_RESISTANCE (Median (min-max)) & & $56.7(46.0-110.3)$ & $54.0(48.0-67.0)$ \\
\hline Tongue_REACTANCE (Mean \pm SD $(\mathrm{N}))$ & 0.911 & $14.7 \pm 2.8(\mathrm{~N}=43)$ & $14.4 \pm 1.6(\mathrm{~N}=12)$ \\
\hline Tongue_REACTANCE (Median (min-max)) & & $14.4(9.8-24.9)$ & $14.2(11.6-17.3)$ \\
\hline Tongue_PHASE ANGLE (Mean \pm SD (N)) & 0.391 & $14.1 \pm 1.6(\mathrm{~N}=43)$ & $14.5 \pm 0.7(\mathrm{~N}=12)$ \\
\hline Tongue_PHASE ANGLE (Median (min-max)) & & $14.1(11.3-19.1)$ & $14.6(13.2-15.5)$ \\
\hline Tongue_TEMPERATURE (Mean \pm SD $(\mathrm{N})$ ) & $0.28^{1}$ & $23.9 \pm 1.6(\mathrm{~N}=43)$ & $23.4 \pm 1.5(\mathrm{~N}=12)$ \\
\hline Tongue_TEMPERATURE (Median (min-max)) & & $23.6(21.3-26.8)$ & $23.2(21.1-25.6)$ \\
\hline
\end{tabular}

